\title{
THREE JOURNEYS: ONE PROJECT
}

\section{OLIVIA MCGEE-LOCKHART, KISHA TANDY, AND ANDREA COPELAND}

\section{ABSTRACT}

The Bethel Project is about the history of Indianapolis' oldest Black church, archival records, preservation technologies, virtual experiences, and collaboration and co-creation among many different departments, heritage institutions and community members. This paper provides three perspectives on this project from individuals who've worked closely together over the past four years. This may seem like a long while to work on one project but for those whose research is community-based it seems about right. Three unique voices will be presented with each telling their own narrative of what she thought when the project started and how her thinking has changed until now. Andrea Copeland is an associate professor in the School of Informatics and Computing whose research focuses specifically on public libraries, community collections, and engagement. Kisha Tandy is the associate curator of social history at the Indiana State Museum who researches African American history and culture. At the center of the project is Olivia McGeeLockhart: Bethel AME Church of Indianapolis' Keeper of History, Indianapolis native, and an Indianapolis Public Schools educator for nearly four decades.

Working on this project produced many questions and was a learning experience. Who were the people who made up the congregation? What did they accomplish? Why is the physical structure important? Why fight to preserve the building? Why preserve the paper collection? What do these records tell us about the neighborhood and the African American community in downtown Indianapolis? What led the congregation to the point of selling? How do you move forward? Everyone associated with this project will have various views, journeys if you will in response to the aforementioned questions but we can write with some assurance that we all learned new dates, new names, new circumstances as a result of this journey that had an impact on what we now believe.

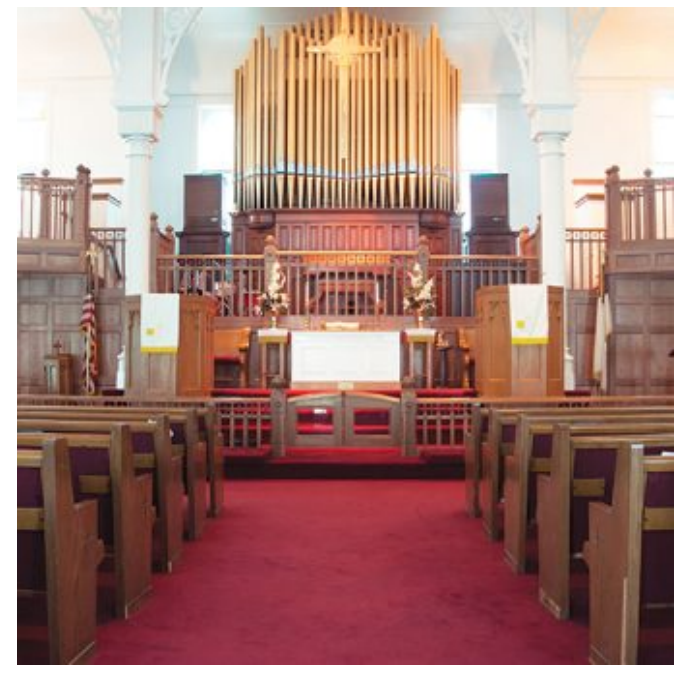

Photo 1. The altar in the Bethel AME Church

\section{OLIVIA MCGEE-LOCKHART}

Lockhart is a remarkable woman in so many ways. In over three-quarters of a century, she has witnessed much positive social progress but also in that time endured some discrimination and denial of equitable access to opportunities solely because of the color of her skin. One day I asked her, "do you ever feel anger regarding what your life could have been like if 
our social systems were just?” She replied, “No, I’ve always felt like I was right where I needed to be, doing what was needed to be done.” That has certainly been the case with the Bethel project.

Until this project, she had not been in the news. Over the past four years, she's been interviewed by Amos Brown on his radio show, the Indy Star, the Indianapolis Monthly, Fox 59, and Wish TV. (See the reference section at the end of the article for publications and media related to this project.) Her love of the Bethel congregation, history, and this city inspired her to connect with new partners and allies outside of the church community to share Bethel's amazing story of strength and accomplishment. Given the historically significant African American community and landscape that existed before the IUPIU campus, Olivia is asked on occasion, "Are you sure it's okay to join with IUPUI to share our story?" She tells them that she believes intentions have changed and she senses a sincere desire on the part of IUPUI and Indianapolis' heritage institution partners to respect, remember and reflect on the contributions made by African Americans that occurred long before the campus arrived.

An interview with Lockhart conducted by Copeland will provide her perspectives on this project and how she came to a place where she could make that statement with confidence. Given the power and importance of her voice in this project, you are encouraged to view a short video of her talking with a reporter from the Indy Star (Lewis, 2016).

The excerpts provided below are from the interview with Copeland on August 24, 2018 at the Lincoln Square Diner in Indianapolis, Indiana.

\section{Getting to Know You}

Andrea: $\quad$ What did you think when you first met me?

Olivia: $\quad$ Don't make me laugh!

Andrea: $\quad$ You can be honest.

Olivia: Well, the fact that we just got through saying, it's been four years. I'm trying to remember. Tell me, where were we? When we met?

Andrea: $\quad$ We were in Spade Park Library, public lib-Rodney Freeman. We met at Rodney's. He had his Project-Back-Up group.

Olivia: Oh yeah.

Andrea: $\quad$ You brought in those amazing photos.

Olivia: Okay. Right.

Andrea: $\quad$ That was the first time I met you. The photos of women who were dressed as nurses, who were members of the Nurses Corps of Bethel.

Olivia: I was on the sidelines. I was watching, listening to all these people talk. It was an easy kind of thing, but I was not thinking about you individually, but I'm thinking, "I'm sitting here with all these librarians ... It was interesting, but I wasn't ready to jump into a whole lot of work at that time. So I backed off. It was like, "Okay, you're just one of the other librarians, "... to know what we'd be doing right now: that never crossed my mind.

Olivia: $\quad$ Miss Frances used to say to me, "Now, be careful about who you allow to see our papers and stuff like that." She said, 
"You know, we've got to be careful some folk can't tell our story like we tell it. Some folks take our stuff and they run with it and get all the credit."

Andrea: $\quad$ She's not wrong. She speaks the truth.

Olivia: I was holding back, you know, just trying to see -- what was going on!

Andrea: $\quad$ I could tell.

Olivia: $\quad$ What else were you trying to do here.

And it wasn't so much, it wasn't against you as an individual or anything like that. It was just the caution that Black folks have had to take all of their lives. And I said, "So, you have to" ... they talk so much about this at church, "Having discernment about people." After a while, you can just about figure that out. Of course, if you ever get crossed by anybody, then you say, "Okay, you close shop all together, you won't share a thing except among persons that you really know and trust." You have been a good girl. You've been fantastic. Because after you sat down when you came here to the Lincoln Square Diner, I said, "Oh, shoot." I wrote a little poem about you. Andrea: $\quad$ You did? Oh my gosh! I gotta see this poem.

\section{Shared Cultural Identity}

Andrea: $\quad$ I have said that had there not been an African American archivist and an African American curator, I sincerely doubt that Olivia would have felt as comfortable in trusting the church's history and their archive. I think having African Americans in those positions helps to establish trust in these institutions where there had been a lack of trust.

Olivia: $\quad$ Yes, right.

Andrea: $\quad$ Since the team members were African American, did that help you in terms of opening up this archive to the greater community?

Olivia: $\quad$ Oh, yes. Not even realizing that Rodney was moving on in a different direction, or at least no longer be present, enough happened with him and through him to venture out. Rodney Freeman was a direct link for considering any efforts toward sharing our treasure. Rodney, too, is a young, gifted African American -- a true guardian.

Andrea: $\quad$ Agreed.

Olivia:

With what belongs to us.

Olivia:

And then making an acquaintance, in addition to that, with genuine people, based on his recommendations ... It does make a difference. It really does. You know, it pulls so many commonalities together, when that happens.

Andrea: $\quad$ Was having Wilma Moore, a Black woman, and somebody with amazing archives credentials related to Black history. Did that help inspire trust? Is that what helped you trust an institution to represent the heritage and history of the church? Did that give you confidence? 
Olivia:

Andrea: $\quad$ Not much.

Olivia:

Andrea:

Olivia:

Andrea:

Olivia:

Andrea:

Olivia:

Andrea:

Olivia:

Andrea: it."

\section{Yeah.} Yes.

You know?
Yes. Absolutely. She was saying, "Now

Olivia. I can't tell you what to do, but ... you know this might be the best option to make sure the history of the church never gets lost." I said, "Yeah, I know, I know." She said, "Well, just think about

Just talking about this now, I'm thinking about the difference between Wilma's age and mine.

No, it's not much. But it was enough for me to say, "Well, if we moved it back into history, when I was graduating from high school, Wilma was in whatever elementary grade somewhere along the line." I said, "Now, here it is in reverse, where she says, 'Okay, now, you have to get involved ... Come on. Let's get this done."'

Wilma being of the same sex, of the same ethnic group, of the same everything, and then for me to having taught her youngest daughter just me our working relationship more binding.

Yes, see, that was a triangle thing: a triangular sisterhood connect.

Oh yeah, yeah.

It took a lot.

Yeah. Right.

It took a lot.
Olivia:

And when, what was it, Kisha had said,

"One of my favorite photos is of you, Wilma, and I, looking at that journal," you know, that kind of thing.

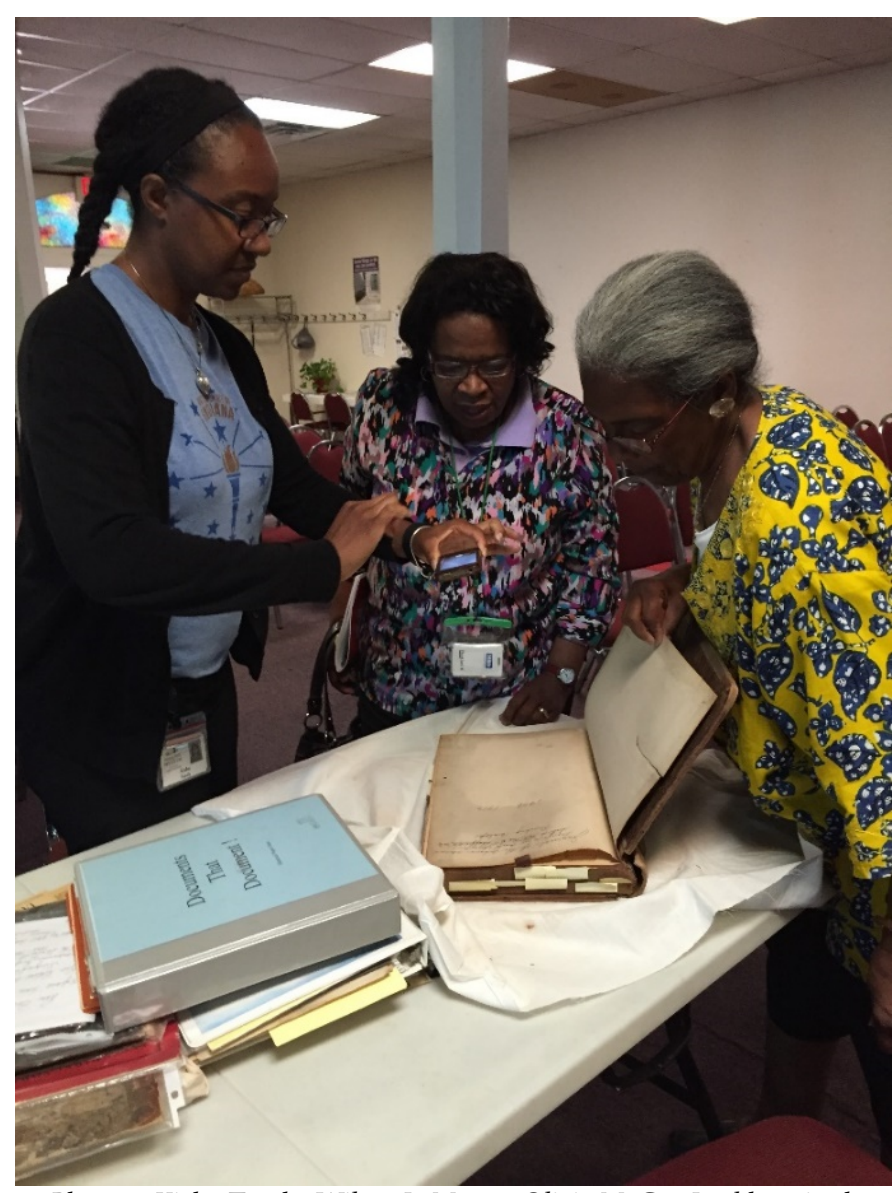

Photo 2. Kisha Tandy, Wilma L. Moore, Olivia McGee-Lockhart in the Fellowship Hall of the Bethel AME Church in the spring of 2016.

Andrea: $\quad$ I love that photo.

Olivia: Wilma and I were sitting in the fellowship hall of the church. A couple boxes around and she's looking through them. We sat down and talked a little bit more. She said, "Now, you think about it." And I said, "Well ... " Now right now? I can't remember if I took a minute to think about it or a day, but I 
said, "Okay." I said, "Now what do I

have to do now?"

Prior to that day, Kisha and one of her interns had already started outlining, or at least listing all of the items in various boxes. Wilma said, "Okay, I'll make arrangements for these items to be picked up."

This project took place during a period of great transitions for the Bethel congregants. Given the repairs needed to the building, the displacement of African Americans from the neighborhoods surrounding the church, and a resulting dwindling and elderly congregation, the church building and property needed to be sold for the congregation to survive. This reality was not an easy one for the then-Pastor Louis Parham, who during all of this was fighting cancer. We had many conversations about this over lunch. Even though the survival of a building paled in comparison to the survival a congregation, he understood deeply that this was a painful loss to the African American historical and cultural landscape. Olivia was faced with making the decision to give (lose) the archive to the Indiana Historical Society during a time of when she and others were already experience a great sense of loss regarding their church building.

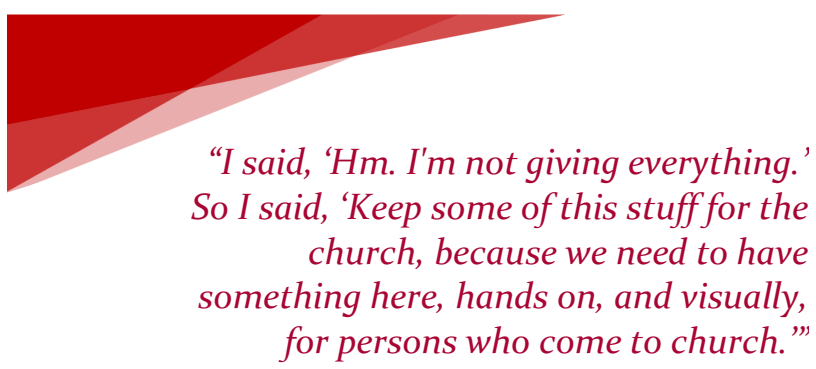

\section{Who Keeps What? Where?}

Olivia: It may have been, Paul, who came along with Wilma to pick up boxes from the church. It was in the sense somewhat of a relief. But at the same time, I said, "Hm. I'm not giving everything." So I said, "Keep some of this stuff for the church, because we need to have something here, hands on, and visually, for persons who come to church." They'll come to the church, first, before they visit the historical society. So I said, "If they think I'm releasing everything, they have another thing coming."

Andrea: $\quad$ They don't call you the keeper of history for nothing.

Olivia: $\quad$ That's right. Those things that I kept are in three-ring binders that says, "Kept for Us." I gave it that title. It is, as of right now, good that I held some things back. Since we're now in the new church, some of those photos have been framed. I went to Goodwill and got my frames, you know?

Andrea: $\quad$ Yeah

Olivia:

When folks step into the archive room, “Ooh, Ahh, Oh! There's so and so. Oh! I remember that!" So those are the kind of conversations they're having. And so many of what I have are duplicates that are at the historical society ... then there's some that they don't quite have, yet, so I've to figure out how to get some of those things to them. 
Andrea: $\quad$ Well, there's always time.

Olivia: $\quad$ Oh, yes. There's plenty of time.

Andrea: It's a living community, a living archive.

I don't think archivists are used to

dealing with living, breathing

organisms. They receive things when

people are dead.

Andrea: $\quad$ We had this kind of intense conversation around where does this archive really belong? Does it really belong at the church itself, the AME Headquarters or at a local institution like the Indiana Historical Society?

Andrea: $\quad$ You were torn, because you could see all sides.

Olivia: $\quad$ Mm-hmm (affirmative).

Andrea: $\quad$ Now, given that-

Olivia: $\quad$ Where am I now on that? No, no, no.

We've moved past that. IHS, the

collection and the virtual experience. All

become part of the local vernacular;

we've been on the local news. None of

that would have happened had we gone

the AME route. But we, Bethel are still

obligated to share with the connectional

AME officer.

Andrea: $\quad$ Do you think there will be greater

impact on the African American

narrative, on our understanding of our

own history, since the collection stayed

in Indianapolis and became a resource

to this community?

Olivia: $\quad$ Yes. Bethel as always been a vital part of Indianapolis history.

Andrea: $\quad$ So we made the right decision?
Olivia:

Yes. I've grown a little bit in the past five years. Our decision was the best action taken. We, Bethel, once again, serve as a model for others. Bethel is in the position to encourage and support other African American landmarks and community histories.

\section{The Teacher Becomes the Student}

Andrea: $\quad$ So what's your biggest take away from working with me and Kisha?

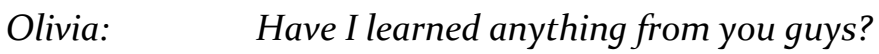
Andrea: $\quad$ Yes, have you learned anything from us? Olivia: Well yeah, because all the technology and stuff. I had no idea about all this stuff. Well, yes, hearing about it, because I'm just not familiar with how it works and all this. But I don't mind sitting back and listening and learning. I don't necessarily have to know how to do it. But I can appreciate the fact that the technology does and has put things in a different perspective and makes it easy to have access to so much. But out of everything, there's some good in it. Just to matriculate with young blood keeps, you young, too, at the same time. You and Kisha, you could have been one of my students.

Andrea: $\quad$ We could have been. Yes.

Andrea: Easily. 
Olivia: $\quad$ For now, it's not role playing, it's just, right now, that's the only thing I can say, role reversal. That's it. That's what it is. I became the student and my students becomes the teacher. That's cool!

\section{KISHA TANDY}

In 1999, I had the opportunity to visit a recently renovated church building on the canal. The interior shined with new paint and upholstery. The building was Bethel African Methodist Episcopal Church. My Bethel journey first began in earnest when I met Mrs. Olivia McGee-Lockhart around 2002. I had visited the building as part of my new duties as a curator at the Indiana State Museum and working to collect artifacts, photographs and stories for the exhibits that would open in 2002. In 2012, Rodney Freeman, a fellow librarian and alum of Indiana Librarians Leading in Diversity fellows, contacted me about a project to scan materials, in particular photographs, from Bethel congregants. A simple request in the grand scheme of things.

\section{Mr. Freeman also contacted Dr. Andrea} Copeland, IUPUI School of Library and Information Sciences (now School of Informatics and Computing) and other librarians along the way. Mr. Freeman left the city in pursuit of professional opportunity shortly after the project began but Dr. Copeland and I continued to discuss the Bethel Project and preserving the archives. In one meeting, the Pastor, the late Louis Parham, shared a dated structural report. An architect reviewed the structure and found parts of the building to be deteriorating but stable. However, this report and financial hardship quickly changed the conversation from preserving documents to saving a treasured building.

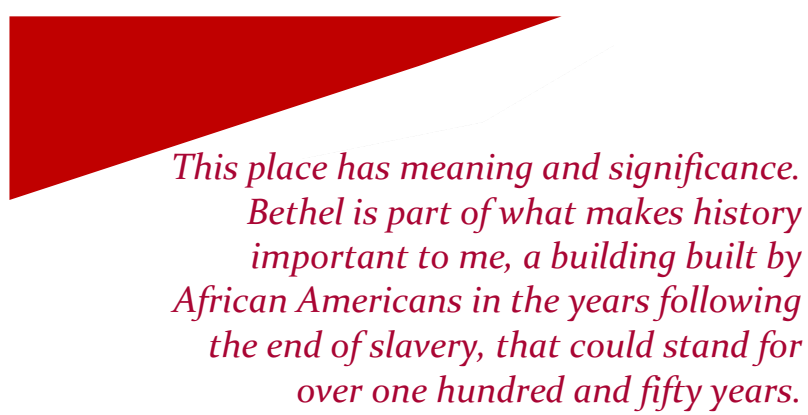

It is important to note how we, Copeland, Lockhart and Tandy (there are many names that will not be mentioned in this essay), arrived to digitizing a collection. I was born and raised in Indianapolis, Indiana. This is home. This place has meaning and significance. Bethel is part of what makes history important to me, a building built by African Americans in the years following the end of slavery, that could stand for over one hundred and fifty years.

Through the discussions and efforts to save the building, one thing remained constant preserving what we could. The historical record of the congregation went beyond the members and served as a chronological record of a community and the annals of the African American community in Indianapolis. Its potential value to researchers both academic and general was significant. This worth as a resource to document the residents of Indianapolis and in particular the Black community in the near Westside of downtown Indianapolis is what led my desire to work with the Bethel Project. With the support of the Chief Curator \& Research Officer and interpretation department as well as the then-CEO of the museum and most importantly the congregation, I worked in earnest to collect and deposit into repository an appreciated history. I along with Jamillah Gabriel, a 
museum studies intern from IUPUI and then librarian at the Purdue Black Cultural Center, began processing what would become the Bethel A.M.E. Church (Indianapolis, IND.) Records 1922-2015 Collection (Moore, Blair, \& Tandy, 2017).

Ms. Frances Connecticut Stout, an English and Spanish teacher at Indianapolis Crispus Attucks High School, served as the archivist and historian for Bethel AME before she died in 2004 at the age of 97. Ms. Stout passed on the archives, memories and a dedication to the history of Bethel to educator, Olivia Lockhart. Due to their painstaking efforts, documents dating from the 180o's are now available to interested scholars. When Jamillah and I arrived to review the collection, the documents were organized and boxed for easier access. We visited the church every Tuesday afternoon for a few hours.

One of my favorite memories was the handwritten notes with phrases like "HISTORY TO BE FILED AND DISPLAYED” “DO NOT DISTURB!”

“THANK YOU!" and "Treasures from Bethel.”

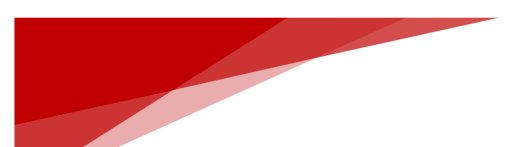

From the wedding announcements to the pupil progress record to the listing for Black businesses in Indianapolis, these records shed light on the community.

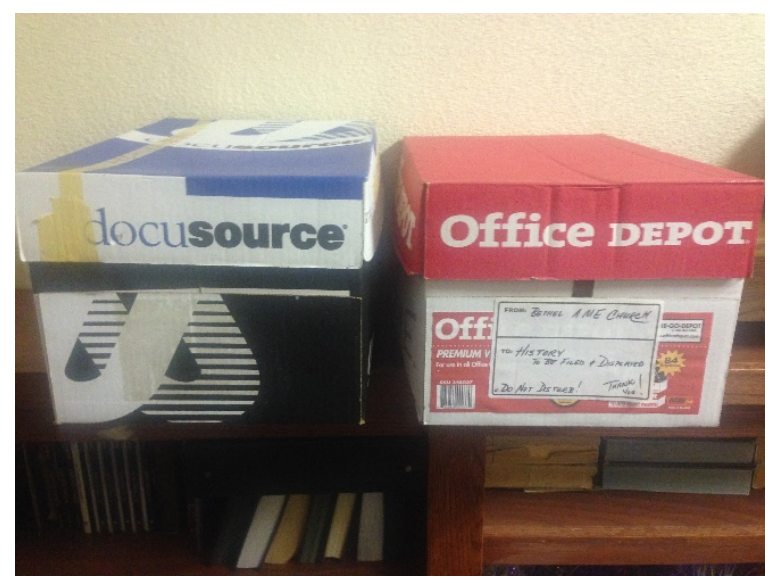

Photo 3. Boxes from the church archive

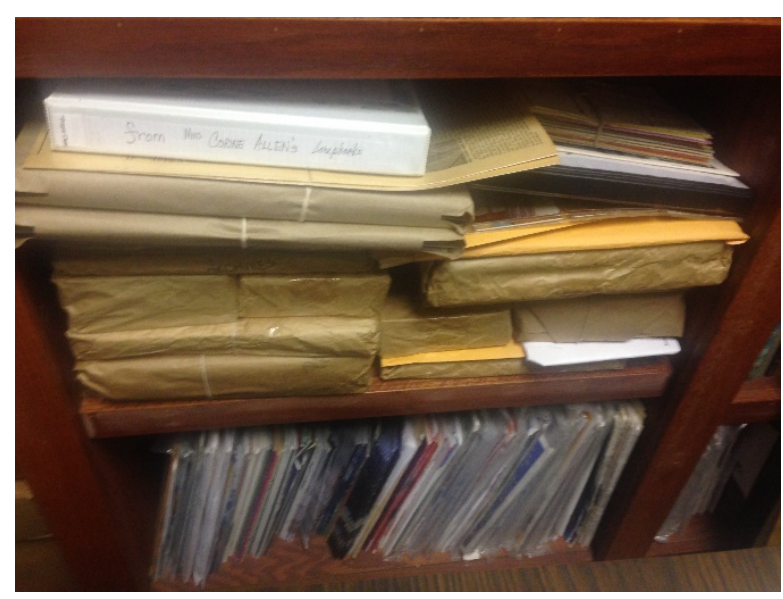

Photo 4. Manuscripts and church publications in the church archive.

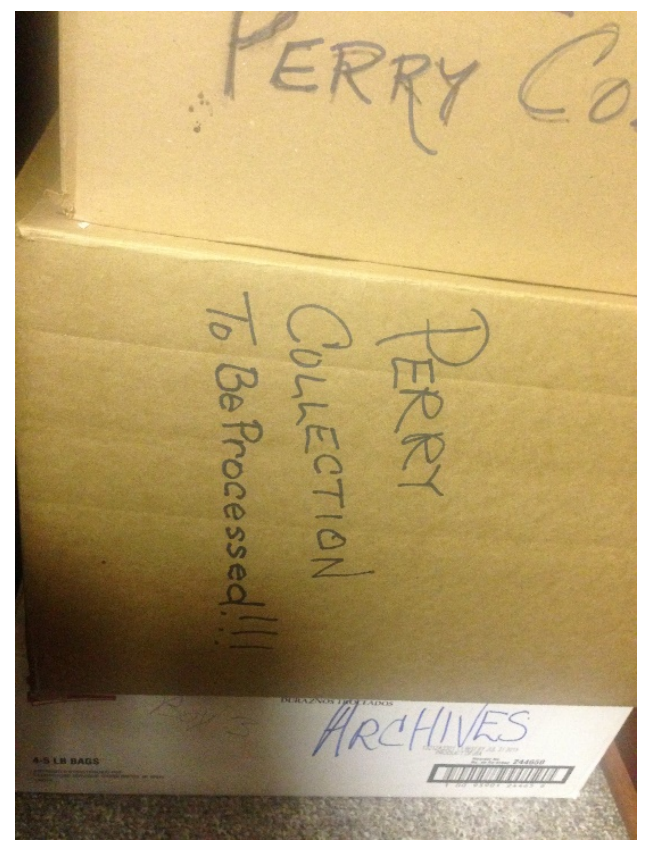

Photo 4. Boxes ready to be shipped the Indiana Historical Society archive 
By the time that the archives went to the historical society in May 2016 to be completely processed and organized into folders for public use by archivist Wilma L. Moore and Lyndsey Blair, Ms. Gabriel had reviewed at least nine boxes of manuscripts, binders, bags, loose items, scrapbooks, packages, and photographs. The contents included substantial evidence of the events of the congregation, however, as a researcher; it was the individual, family and neighborhood records that caught my attention. From the wedding announcements to the pupil progress record to the listing for Black businesses in Indianapolis, these records shed light on the community. The Bethel archives are a community chronicle and for me the project was always about the institutions physical location as one of the last African American presences on the canal and role as a beacon of progress in the city as opposed to religion.

We lost two important people along this journey. Mrs. Wilma L. Gibbs Moore, longtime archivist at the Indiana Historical Society, community historian and mentor to many passed away on April 18, 2018. The Bethel Collection was one of the last collections that she processed. It was her goal to complete before leaving the society; she reached that goal. Louis Sidney Parham, Rev., the Pastor at Bethel during the transition from downtown to its current location on Zionsville Road, passed away on June 6. Both were committed to ensuring Bethel's place in Indianapolis, Indiana and national history.

\section{ANDREA COPELAND}

From the start of this project, I was unsure of how best to serve and to research at the same time. This project provided me the opportunity to explore, on the ground, the connections and disconnections among communities, their archives and heritage institutions. Specifically looking for a framework that connects communities with the resources needed to preserve and make more accessible their histories and, in the process, create a more inclusive historical record for us all.

The amazing history of Bethel inspired changes to and motivated risk-taking in my research agenda. When this project started, I did not have tenure and my research was focused in a somewhat different direction, born-digital community archives rather than ones that exist in tangible formats. Further, community-based research projects are time intensive and I was aware that my clock was ticking, I needed to secure grant funding, to produce and to publish to satisfy institutional requirements for keeping my job. Additionally, I had to be quite careful that my publications were about the process of these connects and disconnects not the Bethel history, even though it was the motivating factor in my research direction. I'm not qualified in any way to tell or interpret it - either by disciplinary background or by lived experience. Writing about the history of Bethel would not establish the scholarly record needed in my discipline for a successful tenure dossier.

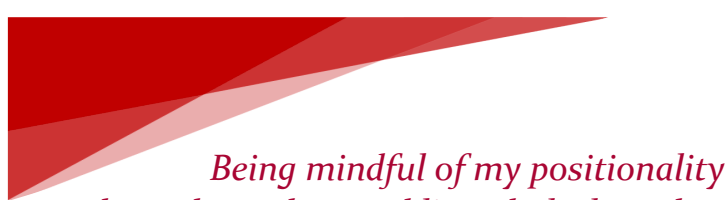
throughout these public, scholarly and personal experiences, I believe was a critical component of the success of this project. By being intentional about my positionality, I was able to facilitate rather than hinder the development of co-creation and the building of equitable partnerships with community members. 
As a white woman from the east coast, my positionality on this project has always been an issue for me and quite possibly for the others, although no one has ever shared concerns. Personally, I was inspired by the Bethel story and I wanted to share it widely in whatever way the congregants felt comfortable. However, I did not want my enthusiasm and passion for having the Bethel voice heard to become the voice of this project. As the saying goes, "how can someone tell her own story, when you are standing on her throat." There were several occasions where I spoke with the media over the course of the past four years and again I was faced with how to position myself in this project. Being mindful of my positionality throughout these public, scholarly and personal experiences, I believe was a critical component of the success of this project. By being intentional about my positionality, I was able to facilitate rather than hinder the development of cocreation and the building of equitable partnerships with community members.

Intellectually, I began this project with a desire to gain a better understanding about how to build a more inclusive infrastructure to support the access and preservation of diverse histories. I focused early on the technical and institutional affordances and constraints. But as time progressed and with reflection, I've learned that while technology and institutional resources are important, any infrastructure of support has to be built on a diverse profession. Without diversifying the profession, our local and national histories will remain exclusive. If Wilma Moore and Kisha Tandy where not there to serve in their capacity as archival and museum professionals, none of this work would have been possible. Therefore, before we can address the technical and organizational structures that support access to diverse archival collections, we need to build professions that reflect the great diversity of human experiences.

This journey has been full of emotions. At the start, I was in awe of the archive and Olivia.

The archive evidenced a powerful history of human strength and triumph: The Bethel AME Church, built in the shadow of slavery, housed congregants who contributed the economic and civic development of our city as they actively worked to improve the quality of life for the city's African American citizens.

Olivia McGee-Lockhart, while she wrote a poem about me, I'm not sure I have the words to describe her justly. She is wisdom, strength, and compassion She is funny and loving. She is my friend.

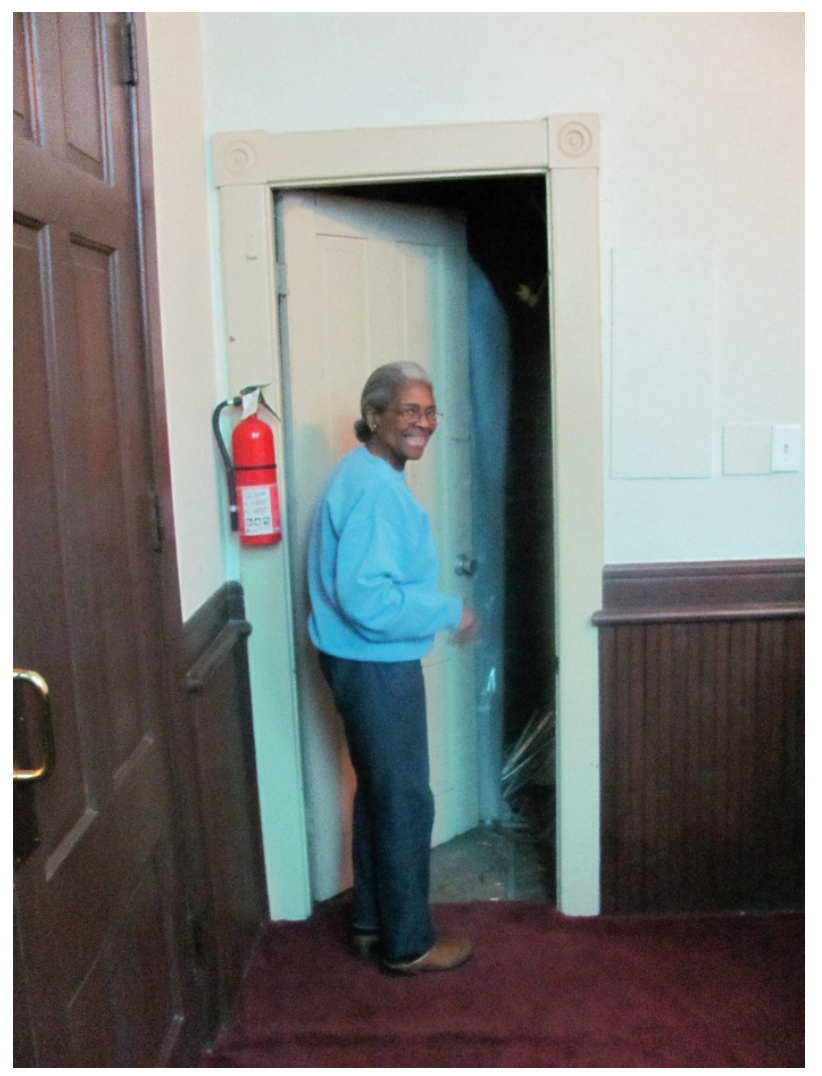

Photo 6. Olivia McGee-Lockart opening the door to the church's bell tower at 414 W Vermont Street 
With the realization of the impending sale of the church building, I became angry that the city didn't seem to want to save this national treasure. Where was this respect for those who had gone before us? Access to one's cultural heritage is a human right and the African American footprint from downtown was and is being steadily erased. This anger turned to sadness when the church was to be sold to become a hotel and would not be transformed into something for the community like an African American Heritage Center. Real tears and letters to Oprah. Not answered. Capitalism won. Hotels generate significant taxes for cash starved cities with mounting physical and social infrastructure needs.

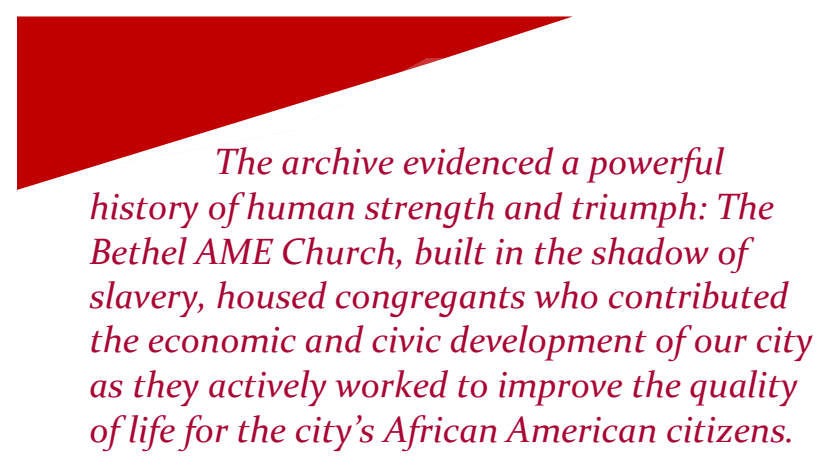

Fortunately, the building will be preserved (with thanks to Indiana Landmarks) and repurposed.

With the forthcoming renovation of the church, a virtual sanctuary was built on a $3 \mathrm{D}$ imaging scan of the sanctuary. This work was done in partnership with my colleagues Zeb Wood and Albert William in Media Arts and Science. Virtual Bethel is a completely born-digital archive of the church building and with that I've come full circle to my initial interest in digital community archives.

My re/search for a framework that connects communities to heritage institutions to build a more inclusive history has fundamentally changed because of this project. I now view diversification of the profession as the most critical element. Kisha Tandy and I are working with others in our community to increase the representation of persons of color in libraries and archives. The successes gained through the Bethel project towards the goal of creating a more inclusive history has created momentum towards future projects. Our first step was to create an endowed scholarship in honor of Wilma L. Moore. The purpose of this scholarship is to remove economic barriers from those individuals from underrepresented backgrounds that would otherwise want to join the heritage professions. We are just getting started and welcome your engagement with us.

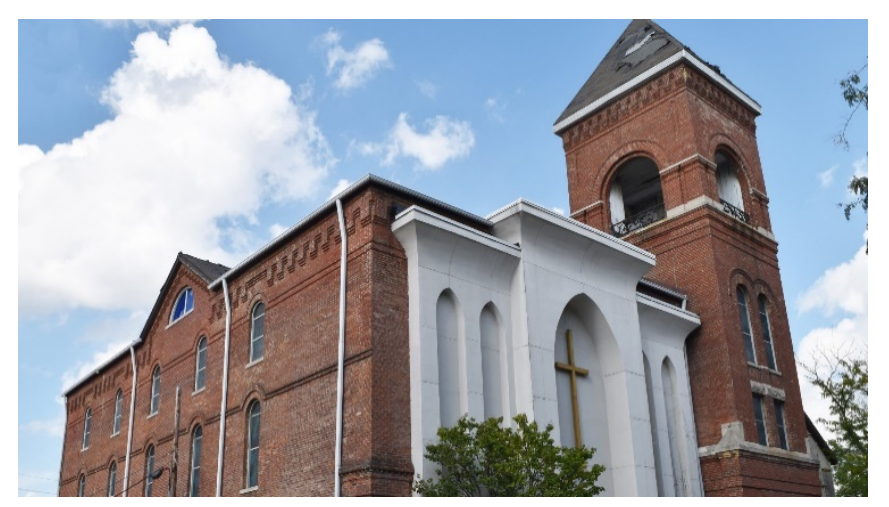

Photo 7. Bethel AME Church, located in downtown Indianapolis. 


\section{REFERENCES}

Amos Podcast. (2015, August 20). Is Indy's oldest black church in danger?

https://praiseindy.com/2066304/amospodcastaug-20-is-indys-oldest-black-churchin-danger-in-peril-2-black-lawmakers-pushingfor-police-bodycams-dashcams/

Donnelly, B. (2018, January 29). Get an exclusive look inside Bethel AME Church as developers plan hotel. https://www.wishtv.com/news/localnews/get-an-exclusive-look-inside-bethel-amechurch-as-developers-plan-hotel/1096655821

Donnelly, B. (2018, February 22). Preserving the legacy of Indy's Bethel AME Church.

https://www.wishtv.com/news/indiananews/bethel-ame-church-indianapolislegacy/1096554021

Donnelly, B. (2018, February 22). Hidden History: Bethel AME Church.

https://www.wishtv.com/news/hidden-historybethel-ame-church/1095915036

Copeland, A. (2017). The Bethel AME Church Archive: partners and participants. In Participatory Heritage. London: Facet, pp. 15-24. https://scholarworks.iupui.edu/bitstream/han dle/1805/12030/Copeland-2017-BethelAME.pdf

Copeland, A., Wood, Z., Spotts, L., \& Yoon, A. (2018). Learning through virtual reality: Virtual Bethel case study. iConference 2018 Proceedings. Sheffield, England.

http://hdl.handle.net/2142/100230

Fox 59 News. (2015, September 9). Developers looking to purchase historic Indianapolis church, community fighting to save it. https://fox59.com/2015/og/og/developers- looking-to-purchase-historic-indianapolischurch-community-fighting-to-save-it/

Heckert, A. (2016, May 3). The changing face of Indiana Avenue. Indianapolis Monthly. http://www.indianapolismonthly.com/newsopinion/changing-face-indiana-avenue/

Lewis, O., (2016, April 8). Indy's oldest AfricanAmerican church sold for hotel space. Indy Star. Retrieved from https://www.indystar.com/story/news/2016/04/ o8/indys-oldest-african-american-church-soldhotel-space/827657441

Lewis, O. (2015, August 22). Bethel AME fights to keep legacy alive. Indy Star. Retrieved from https://www.indystar.com/story/news/2015/08 L22/bethel-ame-fights-keep-legacyalive/32209385/

McGill, N. (2017, February 23). Indy's Oldest Black Church get "Digital Restoration." Fox 59 News. https://fox59.com/2017/02/23/indys-oldestblack-church-gets-digital-restoration/

Moore, W., Blair, L., \& Tandy, K. (2017, January). Bethel A.M.E. Church (Indianapolis, Ind.) Records 1922-2015. Retrieved from https://indianahistory.org/wpcontent/uploads/bethel-ame-church-recordsindianapolis-indiana.pdf

Mullins, P. (2016, April 15). African-American Heritage in the Post-Renewal City. Archaeology and Material Culture (blog). https://paulmullins.wordpress.com/2016/04/15 Lafrican-american-heritage-in-the-postrenewal-city/

Murillo, A. P., Spotts, L., Copeland, A., Yoon, A., and Wood, Z. (February 2018). Complexities of 
Digital Preservation in a Virtual Reality

Environment, the Case of Virtual Bethel. In

International Journal of Digital Curation:

International Digital Curation Conference 2018

Proceedings. Barcelona, Spain.

Reed-Woodard, M. (2018, August 16). Scholarship

named after local historian Wilma Moore.

Indianapolis Recorder.

http://www.indianapolisrecorder.com/educati

on/article 17d3c294-a16e-11e8-b5e9-

93c2c2506afi.html

Virtual Bethel Project.

https://comet.soic.iupui.edu/bethel/ 